The IJA is a peer-reviewed open-access, electronic journal, freely available without charge to users

Produced by the AquacultureHub non-profit Foundation Sale of IJA papers is strictly forbidden

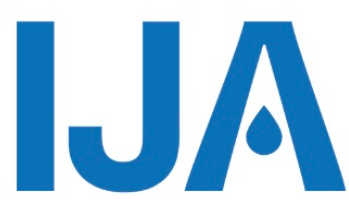

\title{
Effect of Rosemary (Rosmarinus officinalis) and Sage (Salvia officinalis) Essential Oils on Disease Resistance against Aeromonas sobria in Goldfish (Carassius auratus)
}

\author{
Seçil Metin ${ }^{1}$ Behire Isıl Didinen ${ }^{1 *}$ Nimet Kara² ${ }^{2}$ znur Diler ${ }^{1}$ \\ ${ }^{1}$ Isparta University of Applied Sciences, Egirdir Fisheries Faculty, 32260, Isparta, Turkey \\ ${ }^{2}$ Isparta University of Applied Sciences, Department of Field Crops, Faculty of Agriculture, \\ 32260, Isparta, Turkey
}

Keywords: goldfish, rosemary, sage, essential oil, disease resistance, Aeromonas sobria

\begin{abstract}
In this study, the chemical composition and the antibacterial properties against Aeromonas sobria of the essential oils of rosemary and sage in gold fish were evaluated in vitro and in vivo for the first time. The major constituents were eucalyptol $(26.36 \%)$ and camphor $(29.17 \%)$ for rosemary essential oil and eucalyptol $(27.08 \%)$, thujone $(20.52 \%)$ and camphor $(16.99 \%)$ for sage oil. In vitro antibacterial effects of essential oils against $A$. sobria were detected by agar diffusion assay. The in vitro antibacterial effect of rosemary $(20 \pm 2.82 \mathrm{~mm})$ and sage $(18.5 \pm 2.12 \mathrm{~mm})$ essential oils $\left(1000 \mu \mathrm{m} \mathrm{m}^{-1}\right)$ were determined to be strong against $A$. sobria $(p<0.05)$. The effects of the essential oils on the disease resistance of goldfish were also investigated. Fish $(5 \pm 0.15 \mathrm{~g})$ were fed with different concentrations $\left(0,1.0\right.$ and $3.0 \mathrm{ml} \mathrm{kg}^{-1}$ ) of each essential oil for 45 days. After feeding, the fish were challenged with $A$. sobria. Dietary administration of sage essential oil $\left(1.0\right.$ and $3.0 \mathrm{ml} \mathrm{kg}^{-1}$ ) and rosemary oil ( 3 $\mathrm{ml} \mathrm{kg}{ }^{-1}$ ) resulted in a significant reduction in mortality due to $A$. sobria compared to control fish. Our results suggest that these plant oils could provide an alternative for $A$. sobria infection control in aquaculture.
\end{abstract}

*Corresponding author: Tel.:+90 246 2146403, fax:+90 246 2146445,

e-mail: behiredidinen@hotmail.com 


\section{Introduction}

Aquarium fish farming has economic importance and value in the aquaculture sector in recent years. The spread of infectious diseases has accelerated due to the increase in imports and exports of aquarium fish worldwide. So, fish diseases are among the factors limiting aquarium fish farming (Lievens et al., 2011; Mankhakhet et al., 2012). Bacterial infections are often seen in aquarium fish causing significant economic losses. When preventive measures are not taken, the disease is easily transmitted to other fish.

Motile aeromonad septicaemia (MAS), is probably the most common bacterial disease in freshwater aquarium fish (Lewbart, 2001; Jagoda et al., 2014). Among the motile aeromonads, Aeromonas hydrophila, $A$. sobria and $A$. caviae are most commonly associated with fish. $A$. hydrophila has gained much attention as the most common fish pathogenic motile Aeromonas species, but other Aeromonas species may also play an essential role in infection (Beaz-Hidalgo and Figueras, 2012). The goldfish, Carrassius auratus has high susceptibility to Motile aeromonads (Citarasu et al., 2011). It is often an opportunistic infection, characterized by non-specific signs such as fin rot, ulceration, haemorrhages, exophthalmia and dropsy (Beaz-Hidalgo and Figueras, 2012).

Antibiotics are commonly used for the treatment of fish infections in aquaculture. However, they cause significant problems including resistance development in bacteria, residue in fish tissue, suppression of immune system and damage of beneficial microbial flora (Defoirdt et al., 2007; Sapkota et al., 2008). For these reasons, alternative products have become more important for the control of fish diseases (Sivaram et al., 2004). The use of natural substances obtained from plants to control of fish diseases in aquaculture has increased (Goda, 2008; Aly et al., 2008; Ardo et al., 2008; Abdel-Tawwab, 2010).

The in vitro antibacterial activity of several essential oils has been evaluated against major fish bacterial pathogens (Ekici et al., 2011; Türker and Birinci Yıldırım, 2015; Öntaş et al., 2016; Görmez and Diler, 2017; Metin et al., 2017; Baba, 2018; Birinci Yıldırım and Türker, 2018). The essential oil of rosemary exhibited antibacterial activity against Flavobacterium psycrophilum, Lactococcus garviae, Yersinia ruckeri, A. hydrophila, Aeromonas salmonicida, A. sobria, Streptococcus iniae, Edwardsiella tarda and E. ictaluri (Ekici et al., 2011; Mahmoodi et al., 2012; Ostrand et al., 2012; Roomiani et al., 2013; Tural et al., 2019; Yılmaz et al., 2013). However, there is one study about the in vitro antibacterial effect of sage essential oil against fish pathogens: $A$. hydrophila, $A$. salmonicida, Streptococcus agalactiae, Vibrio anguillarum, Y. ruckeri, Enterococcus faecalis and L. garviae (Birinci Yıldırım and Türker, 2018).

Recently, many studies have focused on new natural antimicrobials such as essential oils. It was seen that essential oils could promote growth, develop fish health and increase the resistance to disease in fish because of their addition to fish feed (Zheng et al., 2009; Shehata et al., 2013). Few studies have been conducted on the in vivo antibacterial activity of rosemary and sage in bacterial fish diseases (Abutbul et al., 2004; Zilberg et al., 2010; Gültepe et al., 2014; Terzioglu and Diler, 2016).

Rosemary (Rosmarinus officinalis L., Lamiaceae) and sage (Salvia officinalis L., Lamiaceae) are two spices widely used in folk medicine for their antibacterial, antitumoral, antidiabetic and antioxidant activities (Lo Presti et al., 2005; Khedher et al., 2017). Rosemary and sage have been extensively studied for their antioxidative and antimicrobial activity. Especially, sage has shown strong antibacterial activities (Wu et al., 2012). The antimicrobial activity of Salvia officinalis was attributed to the presence of 1,8-cineole, athujone and camphor (Pierozan et al., 2009). The major components determined in $R$. officinalis essential oil were 1,8-cineol, camphor, a-pinene, bornyl acetate, limonene, borneol, camphene, a terpineol, linalool, $\beta$ pinene, $\beta$ caryophyllene and myrcene (ChávezGonzález et al., 2016). The antimicrobial activity of $R$. officinalis was related to the presence of a-pinene, bornyl acetate, camphor and 1,8-cineole (Genena et al., 2008). The aim of the study was to determine the in vitro and in vivo antibacterial effects of rosemary (Rosmarinus officinalis L.) and sage (Salvia officinalis L.) essential oils against Aeromonas sobria causing Motile Aeromonas Septicemia in goldfish (Carassius auratus). 
Plant materials

\section{Materials and Methods}

In this study, sage (Salvia officinalis L.) and rosemary (Rosmarinus officinalis L.) were used as plant materials. The samples during the blooming stage were taken from the experimental farm of the Agriculture Faculty, Isparta Applied Sciences University. The plants were dried in the shadow and the stem parts were separated after drying. The leaves of sage and rosemary plants were used to obtain their essential oils.

Essential oil isolation and analyses

$500 \mathrm{~g}$ plant samples in $1.5 \mathrm{~L}$ water were extracted by hydro-distillation for 3 hours using Clevenger apparatus according to the standard procedure described in European Pharmacopoeia for determining the oil content ( $\mathrm{v} / \mathrm{w} \%)$. The composition of essential oil was analyzed using gas chromatography-mass spectrometry (GC-MS).

CP-Wax $52 \mathrm{CB}(50 \mathrm{~m} \times 0.32 \mathrm{~mm}$; film thickness $=0.25 \mu \mathrm{m})$ was used as the column for determining the essential oil components of the plants. GC/MS analysis was employed under the following conditions: Oven temperature program, $40{ }^{\circ} \mathrm{C}$ raised to $250{ }^{\circ} \mathrm{C}$ at a rate of $4{ }^{\circ} \mathrm{C} / \mathrm{min}$ and then kept at $250^{\circ} \mathrm{C}$ for 5 minutes. Injection block temperature 250 ${ }^{\circ} \mathrm{C}$, detector temperature $250{ }^{\circ} \mathrm{C}$, carrier gas and helium at flow rate of $20 \mathrm{ml} / \mathrm{min}$. Each component was identified by comparison from the Wiley, Nist, Tutor, FFNSC library of mass Spectra. The component amount was determined by proportioning the relative blocks of the peak areas to the total peak area.

\section{In vitro antibacterial activity}

Well diffusion agar assay

Well diffusion agar assay (WDAA) was used to determine the antibacterial activity of sage and rosemary essential oils against Aeromonas sobria. The pathogen has previously been isolated from diseased yellow tail cichlid (Pseudotropheus acei) by Kubilay et al. (2019). Pathogenic bacteria were grown in Tryptose Soy Broth (TSB) for $24 \mathrm{~h}$ at $25^{\circ} \mathrm{C}$, and $100 \mu \mathrm{L}$ of each culture was mixed into $100 \mathrm{ml}$ of melted Tryptose Soy Agar (TSA). After solidifying and drying for 15-20 minute, wells were punched (diameter=3 $\mathrm{mm}$ ) and $30 \mu \mathrm{L}$ of different concentrations prepared with $96 \%$ ethanol (the test concentrations: $1000,500,250,125$ and $62.5 \mathrm{\mu} \mathrm{ml}^{-1}$ ) added to wells in triplicates. Controls were prepared using $96 \%$ ethanol. Plates were incubated at $25^{\circ} \mathrm{C}$ for $24 \mathrm{~h}$ and observed for inhibition zones around the wells. The antibacterial activity of plant extracts was interpreted as proposed by Bansemir et al. (2006). Inhibition zones $>15 \mathrm{~mm}$ were categorized as strong activity, from 8 to $15 \mathrm{~mm}$ as moderate activity, and from 1 to $8 \mathrm{~mm}$ as weak activity.

\section{Fish and experimental design}

240 healthy goldfish (average weight $5 \pm 0.15 \mathrm{~g}$ ) were produced at the a commercial aquarium farm. The health status of fish were examined and observed immediately upon arrival in the aquariums and with 15 day intervals thereafter according to standardized laboratory procedures (Austin and Austin, 1989). Fish were randomly distributed in duplicate between twelve aquariums $(50 \mathrm{~L})$ with stocking density of 20 fish per aquarim. After the acclimation period ( 15 days), fish were fed for 45 days with basal diet (commercial aquarium fish feed: crude protein $16 \%$, crude lipid 2.5-5\%, digestible energy $2200 \mathrm{kcal}$ $\mathrm{kg}^{-1}$ ) (control) and basal diet supplemented with rosemary and sage essential oils at 1.0 and $3.0 \mathrm{ml} \mathrm{kg}^{-1}$ concentrations. Experimental groups were fed by hand, ad libitum twice daily. Water was changed daily at a rate of $\sim 10 \%$ of the total volume. Water quality parameters were measured as follows: temperature $24^{\circ} \mathrm{C}$, dissolved oxygen $6 \mathrm{mg} \mathrm{L}^{-1}$.

\section{In vivo antibacterial activity}

Disease resistance

After 45 days of feeding, a challenge test was performed on each experimental group with A.sobria. The challenge test was done in 2 replicates where 16 fish from each group ( $8 \mathrm{fish} /$ replicate) were transferred to aquarium. Fish were infected with $A$. sobria by i.p. injection of bacterial suspension containing $1.1 \times 10^{9} \mathrm{cfu} \mathrm{ml}^{-1}$ (LD50 dose). Mortality was 
recorded daily for 15 days. The confirmation of the infection was accomplished after reisolating the bacteria from the dead fish. $A$. sobria was isolated from the liver and kidney of diseased tilapia. The relative percent survival (RPS) was calculated according to Amend (1981).

RPS $=(1-\%$ mortality in experiment group $/ \%$ mortality in control $) \times 100$

Statistical analysis

Data (zone diameters and mortality rate) were assessed by one way analysis of variance ANOVA SPSS 17.0 package program (SPSS Inc., Chicago, IL, USA). Duncan's multiple range tests were used to determine the significant variation $(p<0.05)$ and the significance level was chosen as $\mathrm{P}=0.05$.

\section{GC / MS analysis}

\section{Results}

The components of sage and rosemary essential oils by GC-MS are given in Table 1. A total of 42 components in sage and 39 in rosemary were identified. Eucalyptol (1,8-cineole) $(27.08 \%)$, thujone $(20.52 \%)$, camphor $(16.99 \%)$, beta pinene $(4.07 \%)$ in sage; eucalyptol $(26.36 \%)$, camphor $(29.17 \%)$, borneol $(7.34 \%)$, alpha pinene $(6.72 \%)$ camphene $(4.95 \%)$ in rosemary were determined.

In vitro antibacterial activity

In this study, sage and rosemary essential oils at concentration of $1000 \mu \mathrm{ml}^{-1}$ against $A$. sobria showed strong inhibitory effect $(p<0.05)$ (Table 2$)$. The maximum inhibition zone $\left(1000 \mu \mathrm{m} \mathrm{ml}^{-1}\right)$ of the essential oils of sage and rosemary againts $A$. sobria were in $18.5 \mathrm{~mm}$ and $20 \mathrm{~mm}$, respectively.

In vivo antibacterial activity

Challenge test with Aeromonas sobria

In our study, the cumulative mortality rate in all the groups except of those who received rosemary $1.0 \mathrm{ml} \mathrm{kg}^{-1}$ were lower than in the control following the challenge tests. All sage essential oil groups ( 1.0 and $3.0 \mathrm{ml} \mathrm{kg}^{-1}$ ) showed no mortality after challenged with $A$. sobria. Dietary administration of $3 \mathrm{ml} \mathrm{kg}^{-1}$ rosemary oil significantly reduced fish mortality $(p<0.05)$ (Table 3).

Table 1 Essential oil major components of sage and rosemary (\%)

\begin{tabular}{cccc}
\hline Components & R. Time & $\begin{array}{c}\text { Sage } \\
\text { (Area \%) }\end{array}$ & $\begin{array}{c}\text { Rosemary } \\
\text { (Area \%) }\end{array}$ \\
\hline Alpha-pinene & 6.70 & 3.06 & 6.72 \\
\hline Camphene & 7.28 & 3.67 & 4.95 \\
\hline Beta-pinene & 8.33 & 4.02 & 1.36 \\
\hline Beta-myrcene & 8.78 & 1.61 & 0.94 \\
\hline Cymole & 10.35 & - & 1.79 \\
\hline Limonene & 10.60 & 0.88 & 2.03 \\
\hline Eucalyptol (1.8-cineole) & 10.74 & 27.08 & 26.36 \\
\hline Linalool & 14.67 & 3.84 & 2.70 \\
\hline Thujone & 14.77 & 20.52 & 0.12 \\
\hline Camphor & 17.02 & 16.99 & 29.17 \\
\hline Borneol & 18.65 & 2.67 & 7.34 \\
\hline Terpineol-alpha & 20.14 & 1.02 & 2.94 \\
\hline Berbenone & 20.79 & - & 1.86 \\
\hline Linalyl acetate & 23.72 & 1.13 & 0.70 \\
\hline Bornil acetate & 25.84 & 0.75 & 2.83 \\
\hline Caryophyllene & 34.42 & 3.32 & 1.49 \\
\hline
\end{tabular}




\begin{tabular}{ccc}
\hline \multicolumn{3}{l}{ Table $\mathbf{2}$ Antibacterial activity of sage and rosemary essential oils against $A}$. \\
sobria (inhibition zone diameter, $\mathrm{mm}$ ) \\
\hline Concentration $\left(\boldsymbol{\mu} \mathbf{~} \mathbf{~ m}^{\mathbf{- 1}}\right)$ & Sage & Rosemary \\
\hline 1000 & $18.5 \pm 2.12^{\mathrm{b}}$ & $20 \pm 2.82^{\mathrm{c}}$ \\
\hline 500 & $10.5 \pm 2.12^{\mathrm{a}}$ & $16 \pm 5.65^{\mathrm{abc}}$ \\
\hline 250 & $10.5 \pm 0.7^{\mathrm{a}}$ & $18 \pm 5.65^{\mathrm{bc}}$ \\
\hline 125 & $7^{\mathrm{a}}$ & $8.5 \pm 0.7^{\mathrm{ab}}$ \\
\hline 62.5 & $7 \pm 1.41^{\mathrm{a}}$ & $7.5 \pm 0.7^{\mathrm{a}}$
\end{tabular}

Different lowercase letters indicate differences between within each plant extract $(p<0.05)$.

Table-3. Resistance of goldfish fed with different concentrations of essential oils to $A$. sobria

\begin{tabular}{lcc}
\hline Groups & Mortality (\%) & RPS \\
\hline Rosemary $1.0 \mathrm{ml} \mathrm{kg}^{-1}$ & $50^{\mathrm{A}}$ & - \\
\hline Rosemary $3.0 \mathrm{ml} \mathrm{kg}$ & $25^{\mathrm{B}}$ & 50 \\
\hline Sage $1.0 \mathrm{ml} \mathrm{kg}$ & $12.5^{\mathrm{B}}$ & $\mathbf{7 5}$ \\
\hline Sage $3.0 \mathrm{ml} \mathrm{kg}$ & $12.5^{\mathrm{B}}$ & $\mathbf{7 5}$ \\
\hline Control & $50^{\mathrm{A}}$ & -
\end{tabular}

Capital superscripts denote a significant difference between values for groups at cumulative per cent mortality (i.e., differences within columns).

\section{Discussion}

The antibacterial activities of essential oils of medicinal plants have been known for a long time. These activities depend on the type, composition and concentration, processing and storage conditions of the essential oil and on the type of microorganisms and composition of the substrate (Bertini et al., 2005). In this study, forty-two compounds were identified in the essential oil of sage. The 4 major component were eucalyptol (1,8-cineole) $(27.08 \%)$, thujone $(20.52 \%)$, camphor $(16.99 \%)$, beta-pinene $(4.07 \%)$. Other authors have reported sage essential oil with a comparable composition although there are some differences regarding the quantity of the individual compounds (Kırıcl et al., 1996; Delamare et al., 2007; Said-Al Ahl et al., 2015; Craft et al., 2017; Khedler et al., 2017; Çelik et al., 2018; Karik et al., 2018). The rosemary essential oil isolated was mainly composed of five compounds: eucalyptol (26.36\%), camphor $(29.17 \%)$, borneol $(7.34 \%)$, alpha pinene $(6.72 \%)$ camphene $(4.95 \%)$ in this study. A similar composition was observed for the rosemary essential oil obtained by other studies (Shiwakoti et al., 2016; Tomi et al., 2016; Hendawy et al., 2017; Yıldırım, 2018).

Rosemary and sage essential oils have been reported to be highly antimicrobial properties in numerous investigations and have also been shown to be inhibitory to pathogens (Teixeira et al., 2013). The antibacterial activity of rosemary and sage essential oils has been evaluated against major fish bacterial pathogens (Ekici et al., 2011; Mahmoodi et al., 2012; Ostrand et al., 2012; Roomiani et al., 2013; Yılmaz et al., 2013; Birinci Yıldırım and Türker, 2018). In this study, rosemary essential oil at concentration of 
$1000 \mu \mathrm{ml}^{-1}$ (20 mm inhibition zone) against $A$. sobria showed strong inhibitory effect $(\mathrm{p}<0.05)$. Similarly, Tural et al. (2019) observed that essential oil of $R$. officinalis showed inhibitory effect against $A$. sobria (17 $\mathrm{mm}$ inhibition zone). In another study, the rosemary essential oil showed antibacterial effect against $L$. garvieae with a $24 \mathrm{~mm}$ inhibition diameter zone (Mahmoodi et al., 2012). Roomiani et al. (2013) also reported a strong antibacterial effect with inhibition zone of $45 \mathrm{~mm}$ with rosemary essential oil against $S$. iniae. In addition, Birinci Yıldırım and Türker (2018) noted that a strong inhibition effect of the rosemary essential oil againts $A$. hydrophila, $A$. salmonicida, $V$. anguillarum, $Y$. ruckeri, L. garviae and S. algalactiae. However, Ekici et al. (2011) noted that rosemary essential oil did not show antibacterial effect on $Y$. ruckeri, $A$. hydrophila, $V$. anguillarum, $F$. psychrophilum and L. garvieae.

Sage essential oil was observed inhibitory effect against $A$. sobria at a concentration of $1000 \mu \mathrm{ml}^{-1}$ (18.5 mm inhibition zone) in this study $(p<0.05)$. Similarly, Birinci Yıldırım and Türker (2018) reported the best antibacterial effect of sage oil againts $E$. faecalis and L. garvieae.

In the present study, rosemary oil $\left(3.0 \mathrm{ml} \mathrm{kg}^{-1}\right)$ reduced mortality in goldfish after challenged with $A$. sobria. Similarly, several studies reported that rosemary significantly reduced mortality from S. iniae in tilapia (Abutbul et al., 2004; Zilberg et al., 2010; Gültepe et al., 2014).

Sage oil at 1.0 and $3.0 \mathrm{ml} \mathrm{kg}^{-1}$ concentrations reduced mortality from $A$. sobria in goldfish in this study. In contrast, Terzioglu and Diler (2016) reported that dried sage powder (S. officinalis) did not protected against $V$. anguillarum infection in rainbow trout.

As a result of this study, in vitro antibacterial effects of sage oil and in vivo antibacterial properties of rosemary and sage essential oils in goldfish against Aeromonas sobria were reported for the first time. Sage essential oil at 1.0 and $3.0 \mathrm{ml} \mathrm{kg}^{-1}$ concentrations and rosemary oil at $3.0 \mathrm{ml} \mathrm{kg}^{-1}$ showed disease resistance against Aeromonas sobria infection in goldfish. These results indicated that sage and rosemary oils appears to have therapeutic potential in goldfish aquaculture. In future studies, the effects of different derivatives of these medicinal plants against different pathogens in fish species can be investigated.

\section{References}

Abdel-Tawwab M., 2010. Use of green tea, Camellia sinensis L., in practical diet for growth and protection of Nile tilapia, Oreochromis niloticus (I.), against Aeromonas hydrophila infection. International Journal of Fisheries and Aquatic Studies, 41: 203-213. DOI: $10.1111 / j .1749-7345.2010 .00360 . x$

Abutbul S., Golan-Goldhirsh A., Barazani O. and D. Zilberg, 2004. Use of Rosmarinus officinalis as a treatment against Streptococcus iniae in tilapia (Oreochromis sp.). Aquaculture, 238(1-4): 97-105. DOI: 10.1016/j.aquaculture.2004.05.016

Aly S.M., Atti N.M.A. and M.F. Mohamed, 2008. Effect of garlic on the survival, growth, resistance and quality of Oreochromis niloticus. $8^{\text {th }}$ International Symposium on Tilapia in Aquaculture, 12-14 October, Cairo, Egypt, 277-296.

Amend D.F., 1981. Potency testing of fish vaccines. Developments in Biological Standardization, 49: 447-454.

Ardo L., Yin G., Xu P., Varadi V., Szigeti G., Jeney Z. and G. Jeney, 2008. Chinese herbs (Astragalus membranaceus and Lonicera japonica) and boron enhance the nonspecific immune response of nile tilapia (Oreochromis niloticus) and resistance against Aeromonas hydrophila. Aquaculture, 275: 26-33. DOI: 10.1016/j.aquaculture.2007.12.022

Austin B. and D.A. Austin, 1989: Microbiological Examination of Fish and Shellfish. EllisHorwood, Chichester.

Baba E. 2018. In vitro antibacterial effect of orange (Citrus sinensis) peel essential oil against bacterial fish pathogens. Acta Aquatica Turcica, 14 (3): 208-214. 
Bansemir A., Blume M., Schröder S. and U., Lindequist, 2006. Screening of cultivated seaweeds for antibacterial activity against fish pathogenic bacteria. Aquaculture, 252: 79-84. DOI: $10.1016 / j$.aquaculture.2005.11.051

Beaz-Hidalgo R. and M.J., Figueras, 2012: Molecular detection and characterization of furunculosis and other Aeromonas fish infections. In: Carvalho E.D., David, S.D., Silva, R.J. (eds), Health and environment in aquaculture, pp. 97-132. InTech, Rijeka.

Bertini L.M., Pereira A.F., Oliveira C.D.L., Menezes E.A., Morais S.D. and F.A., Cunha, 2005. Perfil de sensibilidade de bactérias frente a óleos essenciais de algumas plantas do nordeste do Brasil. Infarma, 17: 80-83.

Birinci Yıldırım A. and H., Türker, 2018. Antibacterial activity of some aromatic plant essential oils against fish pathogenic bacteria. LimnoFish, 4(2): 67-74. DOI: 10.17216/LimnoFish.379784

Chávez-González M.L., Rodríguez-Herrera R. and C.N., Aguilar, 2016. Essential oils: A natural alternative to combat antibiotics resistance. In: Kon, K., Rai, M. (eds), Antibiotic resistance: mechanisms and new antimicrobial approaches, pp.227-237. Elsevier Academic Press, London, UK.

Citarasu T., Dhas A., Velmurugan S., Viji T.V., Kumaran T., Babu M.M. and T., Selvaraj, 2011. Isolation of Aeromonas hydrophila from infected ornamental fish hatchery during massive disease outbreak. The International Journal of Current Research, 2(1): 3741.

Craft J., Satyal P. and W., Setzer, 2017. The chemotaxonomy of common sage (Salvia officinalis) based on the volatile constituents. Medicines, 4(47): 1-12. DOI: 10.3390/medicines4030047

Çelik S.A., Ayran İ., Kan A. Y., Kan, 2018. Essential oil yield and compositions of sage (Salvia Officinalis L.) cultivated in different province of Turkey. International Journal of Agriculture, Environment and Food Sciences, 2(Special 1): 193-195. DOI: $10.31015 /$ jaefs. 18034

Defoirdt T., Boon N., Sorgeloos P., Verstraete W. and P., Bossier, 2007. Alternatives to antibiotics to control bacterial infections: luminescent vibriosis in aquaculture as an example. Trends in Biotechnology, 25: 472- 479. DOI: 10.1016/j.tibtech.2007.08.001

Delamare A.P.L., Moschen-Pistorello I.T., Artico L., Atti-Serafini L. and S., Echeverrigaray, 2007. Antibacterial activity of the essential oils of Salvia officinalis L. and Salvia triloba L. cultivated in South Brazil. Food Chemistry, 100(2): 603-608. DOI: 10.1016/j.foodchem.2005.09.078

Ekici S., Diler O., Didinen B.I. and A., Kubilay, 2011. Antibacterial effect of some medicinal plant essential oils against bacterial fish pathogens. Kafkas Universitesi Veteriner Fakultesi Dergisi, 17 (Supplement A):47-54. DOI: 10.9775/kvfd.2010.3224

Genena A.K., Hense H., Smania Junior A. and S.M.D., Souza, 2008. Rosemary (Rosmarinus officinalis): a study of the composition, antioxidant and antimicrobial activities of extracts obtained with supercritical carbon dioxide. Food Science and Technology, 28(2): 463-469. DOI: $10.1590 /$ S0101-20612008000200030

Goda A.M.A.S. 2008. Effect of dietary ginseng herb (Ginsana G115) supplementation on growth, feed utilization and hematological Indices of Nile tilapia, Oreochromis niloticus (L.) fingerlings. Journal of the World Aquaculture Society, 39: 205-214. DOI: 10.1111/j.17497345.2008.00153.x

Görmez O. and O., Diler, 2017. Antibacterial activity of some medicinal plants essential oils against fish pathogens. Journal of Yalvac Academy, 2(1): 112-122. 
Griffin M.J., Goodwin A.E., Merry G.E., Liles M.R., Williams M.A., Ware C. and G.C., Waldbieser, 2013. Rapid quantitative detection of Aeromonas hydrophila strains associated with disease outbreaks in catfish aquaculture. The Journal of Veterinary Diagnostic Investigation, 25: 473-481. DOI: 10.1177/1040638713494210

Gültepe N., Bilen S., Yılmaz S., Güroy D. and S., Aydın, 2014. Effects of herbs and spice on health status of tilapia (Oreochromis mossambicus) challenged with Streptococcus iniae. Acta Veterinaria Brunensis, 83(2): 125-131. DOI: 10.2754/avb201483020125

Hendawy S.F., Hussein M.S., Amer H.M., El-Gohary A.E. and W.S., Soliman, 2017. Effect of soil type on growth, productivity, and essential oil constituents of rosemary, Rosmarinus officinalis. Asian Journal of Agriculture and Biology, 5(4): 303-311.

Jagoda S.D.S., Wijewardana T.G., Arulkanthan A., Igarashi Y., Tan E., Kinoshita S., Watabe S. and S., Asakawa, 2014. Characterization and antimicrobial susceptibility of motile aeromonads isolated from freshwater ornamental fish showing signs of septicaemia. Diseases of Aquatic Organisms, 109(2), 127-137. DOI: 10.3354/dao02733

Karik U., Çınar O., Tunçtürk M., Sekeroglu N. and S., Gezici, 2018. Essential oil composition of some sage (Salvia spp.) species cultivated in İzmir (Turkey) ecological conditions. Indian Journal of Pharmaceutical Education and Research, 52(4): 102-107. DOI: $10.5530 /$ ijper.52.4s.83

Khedher M.R.B., Khedher S.B., Chaieb I., Tounsi S., and M., Hammami, 2017. Chemical composition and biological activities of Salvia officinalis essential oil from Tunisia. EXCLI Journal, 16: 160-173. DOI: 10.17179/excli2016-832

Kırıcı S., Özgüven M. and A., Yenikalaycı, 1996. Investigations on medicinal sage in Çukurova region. Workshop Medicinal and Aromatic Plants, 25-26 May, Abstracts, Bornovaİzmir, 39-40.

Kubilay A., Didinen B.I., Metin S., Onuk E.E., Bahadır Koca S. and G., Ulukoy, 2019. First Record of Aeromonas sobria in Yellow Tail Cichlid, Pseudotropheus acei. Bulletin of the European Association of Fish Pathologists, 39(4):178-185.

Lewbart G.A., 2001. Bacteria and ornamental fish. Seminars in Avian and Exotic Pet Medicine, 10(1): 48-56. DOI: 10.1053/saep.2001.19543

Lievens B., Frans I., Heusdens C., Juste A., Janstrup S.P., Lieffrig F. and K.A., Willems, 2011. Rapid detection and identification of viral and bacterial fish pathogens using a DNA array-based multiplex assay. Journal of Fish Diseases, 34: 861-875. DOI: 10.1111/j.1365-2761.2011.01304.x

Lo Presti M., Ragusa S., Trozzi A., Dugo P., Visinoni F., Fazio A., Dugo G. and L.A., Mondello, 2005. Comparison between different techniques for the isolation of rosemary essential oil. Journal of Separation Science, 28: 273-280. DOI: 10.1002/jssc.200400037

Mahmoodi A., Roomiani L., Soltani M., Basti A.A., Kamali A. and S., Taheri, 2012. Chemical composition and antibacterial activity of essential oils and extracts from Rosmarinus officinalis, Zataria multiflora, Anethum graveolens and Eucalyptus globulus. Global Veterinaria, 9(1): 73-79.

Mankhakhet S., Suanyuk N., Tantikitti C., Phromkunthang W., Kriratnikom S., Lerssutthichawal T. and B., Viriyapongsutee, 2012. Diplomonad flagellates of some ornamental fish cultured in Thailand. Songklanakarin Journal of Science and Technology, 34(5): 484-494.

Metin S., Didinen B.I., Mercimek E.B. and A.T., Ersoy, 2017. Bazı bakteriyel balık patojenlerine karşı bazı bitkisel uçucu yağlarının antibakteriyel aktivitesi. Aquaculture Studies, 17(1): 59-69. 
Ostrand S.L., Glenn R.A., Gannam A.L. and K.C., Hanson, 2012. Inhibitory effects of rosemary oil on the in vitro growth of six common finfish pathogens. The North American Journal of Aquaculture, 74(2): 230-234. DOI: 10.1080/15222055.2012.675995

Öntas C., Baba, E., Kaplaner, E., Küçükaydın, S., Öztürk, M. and M.D., Ercan, 2016. Antibacterial activity of Citrus limon peel essential oil and Argania spinosa oil against fish pathogenic bacteria. Kafkas Universitesi Veteriner Fakultesi Dergisi, 22(5): 741-749. DOI: $10.9775 / \mathrm{kvfd} .2016 .15311$

Pierozan M.K., Pauletti G.F., Rota L., Atti dos Santos A.C., Lerin L.A., di Luccio M., Mossi A.J., Atti-Serafini L., Cansian R.L. and J., Vladimir Oliveira, 2009. Chemical characterization and antimicrobial activity of essential oils of salvia L. species. The Journal of Food Science and Technology, 29(4): 764-770. DOI: 10.1590/S010120612009000400010

Roomiani L., Soltani M., Akhondzadeh B.A., Mahmoodi A., Taheri M.A. and F., Yadollahi, 2013. Evaluation of the chemical composition and in vitro antimicrobial activity of Rosmarinus officinalis, Zataria multiflora, Anethum graveolens and Eucalyptus globulus against Streptococcus iniae; the cause of zoonotic disease in farmed fish. Iranian Journal of Fisheries Sciences, 12(3): 702-716.

Said-Al AhI H., Hussein M.S., Gendy A.S. and K.G., Tkachenko, 2015. Quality of sage (Salvia officinalis L.) essential oil grown in Egypt. International Journal of Plant Science and Ecology, 1(4): 119-123.

Sapkota A., Sapkota A.R., Kucharski M., Burke J., McKenzie S., Walker P. and R., Lawrence, 2008. Aquaculture practices and potential human health risks: current knowledge and future priorities. Environment International, 34: 1215-1226. DOI: 10.1016/j.envint.2008.04.009

Shehata S.A., Mohamed M.S. and S., Abd El-Shafi, 2013. Antibacterial activity of essential oils and their effects on nile tilapia fingerlings performance. Journal of Medical Sciences, 13: 367-372.

Shiwakoti S., Zheljazkov V.D., Schlegel V. and C.L., Cantrell, 2016. Growing spearmint, thyme, oregano, and rosemary in Northern Wyoming using plastic tunnels. Industrial Crops and Products, 94: 251-258. DOI: 10.1016/j.indcrop.2016.08.036

Sivaram V., Babu M.M., Immanuel G., Murugadass S., Citarsu T. and M.P., Marian, 2004. Growth and immune response of junenile Greasy Groupers (Epinephelus tauvina) fed with herbal antibacterial active principle supplemented diets against Vibrio harveii infections. Aquaculture, 237: 9-20. DOI: 10.1016/j.aquaculture.2004.03.014

Teixeira B., Marques A., Ramos C., Neng N.R., Nogueira J.M., Saraiva J.A. and M.L., Nunes, 2013. Chemical composition and antibacterial and antioxidant properties of commercial essential oils. Industrial Crops and Products, 43: 587-595. DOI: 10.1016/j.indcrop.2012.07.069

Terzioglu, S. and O., Diler, 2016. Effect of dietary sage (Salvia officinalis L.), licorice root (Glycyrrhize glabra L.), blueberry (Vaccinium myrtillus L.) and echinaceae (Echinacea angustifolia Hell) on nonspecific Immunity and resistance to Vibrio anguillarum infection in rainbow trout (Oncorhynchus mykiss). Acta Aquatica Turcica, 12(2): 110-118.

Tomi K., Kitao M., Konishi N., Murakami H., Matsumura Y. and T., Hayashi, 2016. Enantioselective GC-MS analysis of volatile components from rosemary (Rosmarinus officinalis L.) essential oils and hydrosols. Bioscience, Biotechnology, and Biochemistry, 80(5): 840-847. DOI: 10.1080/09168451.2016.1146066

Tural, S., Durmaz, Y., Urçar, E. and S., Turhan, 2019. Antibacterial activity of thyme, laurel, rosemary and parsley essential oils against some bacterial fish pathogen. Acta Aquatica Turcica, 15(4): 440-447. DOI: 10.22392/actaquatr.549380 
Türker H. and A., Birinci Yıldırım, 2015. Screening for antibacterial activity of some Turkish plants against fish pathogens: a possible alternative in the treatment of bacterial infections. Biotechnology \& Biotechnological Equipment, 29(2): 281- 288 . DOI: 10.1080/13102818.2015.1006445

Wu Y.B., Ni Z.Y., Shi Q.W., Dong M., Kiyota H., Gu Y.C. and B., Cong, 2012. Constituents from Salvia species and their biological activities. Chemical Reviews, 112: 5967-6026. DOI: 10.1021/cr200058f

Yıldırım E.D. 2018. The effect of seasonal variation on Rosmarinus officinalis (L.) essential oil composition. International Journal of Agriculture and Wildlife Science, 4(1): 33-38. DOI: 10.24180/ijaws.381564

Yılmaz S., Ergün S. and N., Soytas, 2013. Herbal supplements are useful for preventing streptococcal disease during first-feeding of tilapia fry, Oreochromis mossambicus. The Israeli journal of aquaculture-Bamidgeh, 833(1): 195-204.

Zheng Z.L., Tan J.Y.W. and H.Y., Liu, 2009. Evaluation of oregano essential oil (Origanum heracleoticum L.) on growth, antioxidant effect and resistance against Aeromonas hydrophila in channel catfish (Ictalurus punctatus). Aquaculture, 292: 214218. DOI: $10.1016 /$ j.aquaculture.2009.04.025

Zilberg D., Tal A., Froyman N., Abutbul S., Dudai N. and A., Golan-Goldhirsh, 2010. Dried leaves of Rosmarinus officinalis as a treatment for streptococcosis in tilapia. Journal of Fish Diseases, 33(4): 361-369. DOI: 10.1111/j.1365-2761.2009.01129.x 